$p$-ISSN 1693-9484, $e$-ISSN : 2621-8313

Majalah Ilmiah Bahari Jogja (MIBJ)

Vol. 19 No. 2, Juli 2021

$(100-111)$

DOI: $10.33489 /$ mibj.v19i2.273

(C) 2021 Sekolah Tinggi Maritim Yogyakarta

\title{
Flouting Maxim in External Radio Communication Aboard Vessel
}

\author{
Sri Sartini ${ }^{1 *}$, Yudhanita Pertiwi ${ }^{2}$ \\ ${ }^{1,2}$ Sekolah Tinggi Maritim Yogyakarta, Jl. Magelang KM 4.4, Yogyakarta \\ * Corresponding Author. E-mail : sartinisri69@gmail.com. Telp : 085725963973
}

\begin{abstract}
Abstrak
Seiring dengan perkembangan teknologi yang semakin canggih, kapal sebagai alat transportasi di laut mengalami banyak kemajuan. Ada bagian kegiatan di atas kapal yang menentukan efektifitas setiap pelayaran kapal yaitu komunikasi di atas kapal. Komunikasi secara intensif dan tepat mengarah pada komunikasi yang efektif. Dalam komunikasi radio, pelanggaran maksim percakapan tidak dapat dihindarkan. Konteks dalam komunikasi radio memainkan peran penting untuk menafsirkan tiap makna ujaran. Penelitian ini bertujuan untuk mengetahui implikatur percakapan yang digunakan di atas kapal dan pelanggaran maksim yang muncul terutama dalam komunikasi radio eksternal. Desain penelitian ini adalah deskriptif kualitatif dimana data diambil dari komunikasi radio antar taruna saat praktik komunikasi radio di simulator kapal. Dari hasil penelitian diketahui bahwa empat jenis pelanggaran maksim dilakukan perwira jaga yang bertugas dalam komunikasi radio. Pelanggaran maksim tertinggi adalah pelanggaran maksim kuantitas sebesar 36,3\%. Pelanggaran maxim terendah yakni maxim kualitas dan cara yakni sebesar $18,2 \%$. Satu pekanggaran maxim lainnya yakni maxim relevansi sebesar 27,3\%. Alasan di balik pelanggaran maksim juga diungkapkan dalam penelitian ini untuk mendapatkan pengetahuan dan praktik terbaik dalam komunikasi radio di atas kapal.
\end{abstract}

Kata kunci: komunikasi radio eksternal, pelanggaran maksim, Simulator anjungan kapal

\begin{abstract}
Along with the development of increasingly sophisticated technology, vessels as means of transportation at sea have progressed a lot. There is a part of activities aboard vessel which determines the effectiveness of every voyage of the vessel which is communication aboard vessel. Communication which occurs intensively and properly leads to effective communication. In radio communication committing flouting maxim of conversation could not be avoided. The radio communication context plays significant role to interpret the meaning of the speech itself. This study aims to determine the conversational implicature used aboard vessel and the flouting maxims which arise especially from the external radio communication. The design of the research was descriptive qualitative in which the data were taken from the radio communication among cadet's radio communication practice in bridge simulator. The finding shows that the four types of maxim flouting were committed by the duty officers on radio communication. The highest maxim flouted was flouting maxim of quantity as much as $36,3 \%$.
\end{abstract}


The less frequent maxim to be flouted was maxim of manner and quality as much as $18,2 \%$. The other $27,3 \%$ was the occurrence of flouting maxim of relevance. The rationales behind the flouting maxims were also revealed in this study to get the knowledge and best practices onboard radio communication.

Keywords: external radio communication, flouting maxim, Bridge simulator

\section{INTRODUCTION}

Recently, various kinds of cargo have been able to be transported by using any types of commercial merchant ships which could carry various kinds of cargo, one of which is a tanker, general cargo, Bulk carriers, freights, and other types of vessels. Due to the increasing demand of vessels as transportation mode, communication aboard vessel plays an important role specially to support the effectiveness of the officer's duties as well as to lead safe voyages. There are two different types of communication aboard vessel which are then classified into internal and external communication. Both are governed by the use of standard maritime communication phrases. Therefore, the use of maritime language is unique. However, those communications are distinguished from others since they are done aboard vessels in which weather, current, wind, speed and many other reasons may hindrance the effectiveness of the communication itself among officer onboard ship. Both communications that might occur pragmatically conveys meaning. Some of it conveys natural meaning which could be generally obtained by the conversational participant or it is literally-dependent (Wang, 2011). On the other hand, some of the communications refer to implied meaning which is context-bound. Commonly, doing a communication is such to obey a cooperative communication principle which firstly proposed by Herbert Paul Grice. Grice (1975) proposed an approach to the speaker and listener's cooperative use of inference.

Cooperative principle underlies a good collaboration and cooperation among the speaker-listener or writer-reader in communication. To achieve a successful conversation or communication, participants must be co-operative to each other or upholding cooperative principles. Good contribution in cooperative principles provides sufficient information to the interlocutor, namely information that is correct, clear, coherent, and relevant to the conversation (Leech, 2014) According to Yule (1996) Cooperative principle was developed and elaborated in four sub-principles. These are called maxims. A maxim is to measure whether the cooperation can be maintained or not. Any violation toward maxims is identical to the failure of being cooperated. However, in some circumstances, speakers do not follow the expectations of the cooperative principle that it means they violate maxims. If this is happened, they will not be as informative as required. Although they do so, they are still naturally interpreted as communicating more than is said. The maxims can be observed in conversation and in other human interaction both spoken or written interaction. According to Grice in (Wang, 2011) the four maxims in Cooperative principles consist of the maxim of quality, the maxim of quantity, the maxim of relevance, and the maxim of manner. 
In the maxim of quality, people should be sincere about what they speak out. They should make their speaking is the one which is true based on nature. Obviously, when someone does not speak correctly based on the fact, it means that he violates or flouts the maxim of quality. The maxim of quantity is related to how informative the statement is. In this maxim, speaker is supposed to make his contribution as informative as it is required for the current purpose. Nevertheless, the speaker may not give his contribution or statement more informative than it is required. Therefore, if the contribution of the speaker is more or less informative than it is required, it will mean that the speaker violate or flout the maxim of quantity. The maxim of relevance is supposed to be the easiest maxim. It points out that the participant or speaker must speak about the precisely same topic. He also avoids asserting something which is irrelevant. On the other word, it tries to make the contribution to be much relevant. If the speaker's saying does not commit relevance to the topic, it will mean that the speaker violates or flouts the maxim of relevance. The fourth maxim is the maxim of manner. The regulations cover many aspects that a standard sentence calls for. It tries to make the contribution to be perspicuous and specific by avoiding ambiguity and obscurity. It must be brief and it must be orderly. Any action of speaking which does not obey the regulations will lead to violation to the maxim of manner.

Examining the use of external communication aboard vessel which uses very high frequency channel is much interesting to conduct. External communication due to external factors such as weather, current, wind direction, speed of vessel, as well as the social relationship among officers aboard vessel might trigger implied meaning. Based on cooperative principles in communication, it was required to know how communication might occur and how the maxim of conversation is somehow violated. There were some related studies discussed almost the same topic. One of it is entitled 'Flouting Of Maxim On English Radio Program In Yogyakarta by (Setyawan, 2021). It discussed more on the occurrence of the flouting maxim conversations between radio announcers and guest within English radio broadcasting program. However, the object of the research was significantly different. Hidayati (2018) writes about "Flout Maxim in the Speech of the Movie Figures Radio Galau Fm: A Pragmatic Study'. It shows the flouting maxim that were also found in radio conversation. However, it was different in the perspective of the object of communication and also it did not investigate the cause of the violation. Another previous study is entitled "The Analysis of Flouting Maxim in Good Morning America Talk show" by (Marlisa \& Hidayat, 2020) which discussed about the flouting maxim upon guest star and host of GMA. Though the focus of the discussion is similar but it has different object of study. Based on the problem and previous studies above, the researcher felt to urgently observed the flouting maxim of conversation that might occur aboard vessel. How maxim conversation is obeyed and how it is flouted. Furthermore, it was required either to comprehend the context to interpret the implied meaning produced. McKay (2006) in Zacharias (2011) states that thick description of context helps to ensure the external validity and transferability. Thus it is also essential to know the context. The researcher used bridge simulator of Sekolah Tinggi Maritim Yogyakarta which consists of main bridge and some 
cubicles as if it reflected the real bridge aboard vessel. It has achieved international approval from International Maritime Organization which is administered by Indonesian sea transportation ministry. Therefore, the bridge simulator laboratory practices became the real setting and resources of the object of the research.

\section{RESEARCH METHODOLOGY}

The design of the research was qualitative study by describing the research object based on the facts that appear as they are. The important of every single word and utterance in this research could not be denied due to the aim of this study to deliberately explain the phenomenon occurred. Therefore, transcribing the utterance data of the use of English external communication onboard vessel was such obligatory to reach the purpose of this study. Thus, in this research, the researcher plays important role as it is the key instrument starting from gaining the data till the conclusion drawing. Since it belonged to qualitative research, the natural setting was required (Creswell, 2014). The setting of external communication onboard vessel was achieved in the bridge simulator practice by the fourth semester cadets of Nautical Science department of Sekolah Tinggi Maritim Yogyakarta. Further (Creswell, 2014) states that qualitative research approaches to data collection, analysis, interpretation and report writing. The data collected in this study were communication utterances from the activities of ship to ship communication and ship to shore communication which contain the flouting of maxim which they were still context-bound.

In analyzing the data, there were some techniques used. Those techniques were completely done after obtaining data which included three activities, namely (1) collecting the data and analyzing it, (2) classifying the data, (3) drawing temporary conclusions, (4) checking the existing data, and (5) drawing final conclusions (Setyawan, 2021). The presentation of the results of the data analysis was done informally, using words and sentences. As it is stated by (Bogdan \& Biklen, 2006) the data collected take the form of words or pictures rather than numbers. Therefore the data were analyzed with all of their richness as closely as possible to the form in which they were recorded or transcribed.

\section{FINDING AND ANALYSIS}

\section{Result of Data and Rationales of Flouting Maxim}

In external radio communication aboard vessel which was shown one of which is from bridge simulator practice, there were several ship to ship and ship to shore communication and also ship to VTS communication that might occur. From some of these communications, it could be understood that there were four types of maxims of conversations from the Grice' cooperative principles were violated.

\section{Flouting of Maxim of Quantity}

Flouting maxim of Quantity occurs when the speaker does not give his contribution or statement more informative than it is required. Further it could be 
said if the contribution of the speaker is more or less informative than it is required, maxim of quantity is being violated.

a. Datum 1

Vessel Traffic Services

Officer of Majapahit Vessel

\begin{tabular}{l}
$:$ MV (motor vessel) Majapahit SOZZ, This \\
is Vessel traffic services. Advice : \\
\hline down to speed four knots before buoy \\
\hline number 5. Over. \\
:Vessel traffic services, this is \\
MV.Majapahit. Advice received. Buoy \\
number 5. Over.
\end{tabular}

:MV (motor vessel) Majapahit SOZZ, This is Vessel traffic services. Advice : slow down to speed four knots before buoy number 5. Over. MV.Majapahit.

It is indicated that maxim of quantity was flouted here. The reason is that the contribution of utterance by radio officer of Majapahit vessel was less informative than it is required. Even though the meaning is quite understandable yet the utterance is less informative. Instead of saying 'advice received', based on standard maritime communication phrases the officer should restate all the utterance again both to ensure the clarity of the information and to ensure that the advice is well received. In term of 'Buoy number 5' seems to be less informative as well since it could be interpreted differently. Whether or not buoy number 5 would be the sign of reducing speed of the vessel should be clearly stated, so that the utterance would be more informative as it should be.

b. Datum 2 .

Finnish coast guard

:MV.Mataram, KL7H, This is Finnish Coast guard. Information: your navigation lights are not visible.over.

Officer of Mataran vessel : Finnish coast guard. This is MV Mataram, KL7H. Information received. I am doing it now.

The radio communication among coast guard and vessel above shows us that violation toward maxim of quantity was very clear here. The reason is due to the response of Mataram radio officer that there might be an information which loss and unclearly interpreted. The response is less informative toward the interlocutor. Finnish coast guard could be questioning whether MV.Mataram will do the right thing as he implied MV Mataram should do which is to directly switch the light on right away. Though MV Mataram radio officer did not ignore the meaning of what was implied by interlocutor, yet he violated the maxim of quantity since he reduced the information which could probably lead to different interpretation.

c. Datum 3

Officer Mataram Vessel : Mayday-mayday-mayday, This is MV Mataram, MV Mataram, Mayday. MV Mataram KL7H,

Majalah Ilmiah Bahari Jogja 104 | http://jurnal.amy.ac.id/index.php/MIBJ/ 
Position:Latitude $50^{\circ} 35^{\prime}$ north, Longitude $001^{\circ} 35^{\prime}$ west. I have heavy leakage, I require immediate assistance.

Officer Majapahit vessel: Mayday, MV. Mataram, MV.Mataram KL7H, This is MV Majapahit. Received mayday. Over. $M V$ Mataram, this is MV Majapahit. My position : Latitude $55^{\circ} 38^{\prime}$ north, Longitude $002^{\circ} 38^{\prime}$ west. Speed 8 knots. ETA 15.30 UTC. Over.

We could see that the radio communication above flouted the maxim of quantity. The implied meaning derived from the context of the conversation was that Mataram vessel needed help from other vessel. However it asked for a help in a very long sentence which is more informative than it should be. On the other hand the interlocutor also replied in such more informative sentence. Though the sentences were understandable but they were not that urgent to reveal in those longer sentences. Therefore it was more informative than what was required.

d. Datum 4

Officer Mataram Vessel : $\underline{M}$. In my port side, This is MV Mataram KL7H, our course One two five degrees, what is your intention?

Officer Majapahit vessel: $\underline{\text { MV Mataram, this is MV Majapahit SOZZ. My }}$ speed 5 knots, I want to turn starboard side before the course of you

The above external communications shows us that it violated the maxim of quantity. When we analyzed the interlocutor which is radio officer of Majapahit vessel, he replied the questions given by locutor more informative than it was required. He did not exactly and precisely respond to the question directly. There was some additional information given by the interlocutor which was not needed in term of obeying maxim of quantity. The utterance 'speed 5 knots' was actually not required. This additional information should not be there. The implied meaning revealed from the locutor was that he wanted to know the intention of the other party. But it was replied in more informative utterance.

\section{Flouting of maxim of Quality}

Flouting maxim of Quality occurs when a speaker does not provide information which is in accordance with reality and in this case a speaker avoids going on record or direct statements. On the other hand, people should be sincere about what they speak out.
a. Datum 5

Officer of Majapahit Vessel

MV.Mataram KL7H, This is $M V$
Majapahit, SOZZ calling you on VHF
channel 16, Do you read me, over?

Majalah Ilmiah Bahari Jogja 105 | http://jurnal.amy.ac.id/index.php/MIBJ/ 


\section{Officer of Mataram Vessel} over.

: MV.Majapahit, this is MV Mataram, come in,

This fact shows us that maxim of quality is flouted here. It is due to the answer of Mataram vessel officer who does not directly answer as it is asked. Logically Mataram's officer should answer whether or not he or she clearly listen to the radio call made by Majapahit's officer. However, he prefers using the sentence or statement which does not directly answered to the question. Moreover, we could see here that Mataram radio officer did not merely tell the truth that he clearly listened or got the point of what was stated by Majapahit radio officer. He tended to use quick utterance which he though simpler. The reason is in communication aboard vessel, practicability and being communicative are all enough.

b. Datum 6

Officer of Majapahit Vessel : MV.Mataram KL7H, This is $M V$ Majapahit, SOZZ please switch to channel $\underline{13, \text { over. }}$

\section{Officer of Mataram Vessel $\quad:$ MV.Majapahit SOZZ, this is MV Mataram KL7H, channel 13, over.}

It is indicated that officer of Mataram Vessel slighly flouted maxim of quality by not telling directly that he would do switching the channel. He flouted maxim of quality in his utterances by saying "channel 13 , over" which implicitly means Mataram's officer did not want to strengthen the previous statement which implicitly state that he would do it. In fact, he has no other choice as well as reason not to admit the suggestion of Majapahit's radio officer. The respond actually showed agreement for switching channel. However, it is stated indirectly, therefore the speaker violated the maxim of quality.

\section{Flouting of Maxim of Relevance}

Flouting of maxim of relevance occurs when speaker's saying does not commit relevance to the topic. To avoid flouting maxim of relevance, speaker must avoid asserting something which is irrelevant. Speaker must make contribution which is always relevant to the context of the statement.

a. Datum 7

Officer of Majapahit Vessel

: MV.Mataram KL7H, MV Mataram KL7H, , MV Majapahit SOZZ calling on channel 14,over?

Officer of Mataram Vessel $\quad$ MV.Majapahit, SOZZ, this is MV Mataram KL7H please spell your name?, over

Majalah Ilmiah Bahari Jogja 106 | http://jurnal.amy.ac.id/index.php/MIBJ/ 


\section{Officer of Majapahit Vessel $\quad$ : MV.Mataram KL7H,This is MV Majapahit $\underline{S O Z Z, \text { I spell Mike-Alpha-Juliet-Alpha-papa- }}$ Alpha-hotel-India-Tango. What is your intention? $\underline{\text { Over }}$}

The above radio communication flouted the maxim of relevance in terms of irrelevant reply revealed by radio officer of Mataram vessel. He was supposed to answer whether or not he got the questions obviously and clearly. However, he even asked back different irrelevant questions which did not denote to the first question. It was simply not precise respond of Mataram's radio officer to produce. Furthermore, in the last response of Majapahit vessel, again he did not produce relevant utterance in which he implied another questions irrelevant to the previous topics by asking the intention of Mataram vessel to do further. Hence the violation toward maxim of relevance occurred here.

b. Datum 8

Officer of Mataram Vessel

: Karang Jamuang pilot station, This is $M V$ Mataram KL7H, calling you on VHF channel 12 , our position is Latitude $47^{\circ} 34.4^{\prime}$ north, longitude $004^{\circ} 32.9^{\prime}$ west, we require pilotage, do you read me? over.

Karang Jamuang pilot station : $\underline{\text { This is Karang Jamuang Pilot station, what is }}$ your ETA?

Specifically, radio officer of Mataram vessel asked question whether or not the pilot station clearly heard the radio call from the vessel due to asking for pilotage assistance. In the radio communication, in fact the maxim of relevance was flouted for the reason that the vessel just wanted to get pilot station response regarding to his questions. However, the pilot station gave a question back for a feedback. In order to obey the maxim of relevance, pilot station should have given an explanation about whether or not he clearly heard the radio call and then would give a pilotage help. Therefore, his feedback question was not matched. Hence flouting of maxim of relevance occurred here.

\section{c. Datum 9}

Officer Mataran Vessel : vessel traffic services, this is Mataram vessel KL7H, information : I am underway.

Vessel Traffic services : MV.Mataram K17H, what is your current speed?

In the conversation, maxim of relevance was flouted. The locutor in this case Mataram vessel only wanted to inform the VTS that he has been underway. However, the interlocutor gave a question for a feedback. Actually to follow the maxim of relevance, he should give an explanation about the process of underway

Majalah Ilmiah Bahari Jogja 107 | http://jurnal.amy.ac.id/index.php/MIBJ/ 
and guidance. Or merely he has just note down the information. Between the locutor and interlocutor utterance was unmatched, Between information given and the respond which is required was so far not different.

\section{Flouting of Maxim of Manner}

Speaker will obey the maxim of manner if the contribution is perspicuous and specific by avoiding ambiguity and obscurity. It must be brief and it must be orderly. Any action of speaking which does not obey the regulations will lead to violation to the maxim of manner.

\section{a. Datum 10}

Officer of Majapahit Vessel: MV.Mataram KL7H, MV Mataram KL7H, This is MV Majapahit, MV Majapahit SOZZ calling you on channel 16,over?

Officer of Mataram Vessel : MV.Majapahit, MV Majapahit SOZZ, this is $M V$ Mataram KL7H please come in.

The officer of both Mataram and Majapahit vessel does the flouting of maxim of manner by producing such long sentences which is actually it is not enough brief. In this context, each officer of both vessels can only ask and answer once, but the two officers provide more repetition. The reason is because they want to ensure that both could listen well each other and get the purpose of their communication. It is due to the fact that aboard vessels where there might be strong wind and external factors outside vessels could affect the communication. Besides, there is also standard maritime communication phrases which already rule the production of communication phrases aboard vessel. However, the analysis of flouting maxim beyond the rule of standard maritime communication phrases itself. Therefore, it is considered to be neutral that this study wanted to reveal the pragmatics aspect from the communication occurred aboard vessel.

b. Datum 11

Officer of Mataram Vessel $\frac{\text { MV.Majapahit, SOZZ, this is MV Mataram }}{\text { KL7H Do you carry any dangerous goods? }}$

\section{Officer of Majapahit Vessel $\quad$ MV Mataram KL7H, this is MV.Majapahit, SOZZ, negative.}

The radio officer of Mataram vessel asked whether Majapahit vessel carried dangerous cargoes, yet he did not get the answer. The interlocutor or MV Majapahit answer was "negative" which is not a yes or no response which was doubtful. MV Mataram would be probably confused. Thus, the interlocutor flouts maxim of manner since his utterances was not really understood by the locutor and it was confusing, not brief and unclear. Though his utterance was not completely understood, the reason of his utterances is collaborative which means that he did not carry hazardous cargoes. 


\section{DISCUSSION}

There were eleven utterances flouted the maxim of conversation based on the external radio communication conducted by the officers on duty in bridge simulator practices. The categorization of the utterance was derived following Grice's cooperative principles which is shown as follows;

Table 1. The Flouted Maxim of Conversation

\begin{tabular}{clcc}
\hline No. & Flouted maxim & Number & Percentage \\
\hline 1. & Maxim of Quantity & 4 & $36.3 \%$ \\
2. & Maxim of Quality & 2 & $18,2 \%$ \\
3. & Maxim of Relevance & 3 & $27,3 \%$ \\
4. & Maxim of Manner & 2 & $18,2 \%$ \\
\hline
\end{tabular}

From table 1 above, we could see that out of eleven data, maxim of quantity was the most frequent to be flouted. There were four numbers of flouting maxim of quantity or it is as much as $36,3 \%$ occurrences. There were two flouting maxims of quality or it is about $18,2 \%$ as it is in the same amount of occurrences with the number of flouting maxim of manner. The second place of most flouted maxim was maxim of relevance which is as much as $27,3 \%$ or exactly there were three occurrences. Each datum had been classified and categorized with rationales of why such flouting maxim was carried out. Hence, it was closely related to the context where and in what situation the speech might take place. The context here became basic element to make interpretation of the implied meaning. Jhon I. Saeed (2005) states that context is culturally bound. Therefore, it became background knowledge which contributes to the utterance interpretation. The culture and nature of officers on board vessel would likely repeat two or three times for one utterance and also tend to be more informative than it is required. For example in the utterance of datum 3 , it is clear that the vessel required immediate assistance however, the vessel had no other choice to make longer utterance so that the information given is more than what is required. Thus, it violated maxim of quantity.

Flouting maxim of relevance became the second place to frequently occur since in aboard vessel the most important thing is to speak understandably, communicatively and practically. Context helped the speakers to easily imply the utterance meaning although the production of the utterance is somehow irrelevant. For example in datum 7, Mataram vessel was eager to know whether Majapahit vessel heard his calling however it was replied irrelevantly by asking back Mataram vessel to spell the name of his vessel. On the other hand, we know that it does not mean if Majapahit vessel did not get the point of Mataram's question. Thus, maxim of relevance was flouted here. Flouting Maxim of quality which were shown in this study revealed that the interlocutor seemed not to speak correctly based on the fact. For example in datum number 5, the interlocutor actually got the point for the question. But instead to answer the question correctly and precisely with the answer of yes or no, he chose to answer in different context

Majalah Ilmiah Bahari Jogja 109 | http://jurnal.amy.ac.id/index.php/MIBJ/ 
yet it had the same implied meaning. There were two occurrences of flouting maxim of manner. One of which was very obvious in datum 11. It showed that the interlocutor did not briefly answer the question of the locutor. Since the answer given was not brief, the implied meaning was little bit ambiguous. Hence maxim of manner was flouted. From all occurrences of the flouting maxim of conversation in this study shows that implied meaning or implicature might happen in communication aboard vessel especially in the external one between ship to ship and ship to shore.

\section{CONCLUSION}

Cooperative principles in communication underlies good collaboration and contribution to make the communication true by its nature, as informative as it is required, brief, and relevant to the topic. However flouting maxim of conversation onboard vessel were carried out due to some reasons. The reasons of flouting maxim of quantity were caused by the context aboard vessel. Giving more information and in one occasion minimizing the information are somehow better to ensure the right interpretation of the interlocutor toward the locutor's utterances. Maxim of quality is flouted mostly due to the reason that it is a routine communication in which every speaker knows what the implied meaning is onboard veesel yet interlocutor reply in different ways by not showing his true understanding about the context. Maxim of relevance is flouted in terms that interlocutor gave reply irrelevantly toward the utterances. However, he really new the implied meaning. The last maxim of manner is flouted in terms of the interlocutor did not reveal the answer directly and clearly to correspond with the utterance. Whatever flouting maxim happens, as long as locutor and interlocutor may convey the messages, opinions, or ideas very well, it is fair to occur.

\section{REFERENCES}

Bogdan, R., \& Biklen, S. K. (1997). Qualitative research for education. Allyn \& Bacon Boston, MA.

Creswell, J. W., \& Creswell, J. D. (2017). Research design: Qualitative, quantitative, and mixed methods approaches. Sage publications.

Grice, H. P. (1975). Logic and conversation, syntax and semantics. Speech Acts, $3,41-58$.

Hidayati, N. N. (2018). Pelanggaran Maksim (Flouting Maxim) Dalam Tuturan Tokoh Film Radio Galau Fm: Sebuah Kajian Pragmatik. An-Nas, 2(2), 248263.

Jhon I. Saeed. (2005). Semantics (2nd edition). In Studies in Second Language Acquisition (Vol. 27, Issue 3, pp. 465-466).

Leech, G. N. (2014). The pragmatics of politeness. Oxford University Press, USA.

Marlisa, R., \& Hidayat, D. N. (2020). the Analysis of Flouting Maxim in Good Morning America (Gma) Talkshow. Englisia: Journal of Language, Education, and Humanities, 7(2), 137. https://doi.org/10.22373/ej.v7i2.6630 
McKay, S. L. (2006). Researching second language classrooms. Routledge.

Setyawan, A. H. (2021). FLOUTING MAXIM ON ENGLISH RADIO PROGRAM IN YOGYAKARTA. ELTICS: Journal of English Language Teaching and English Linguistics, 6(1).

Wang, H. (2011). Conversational Implicature in English Listening Comprehension. Journal of Language Teaching \& Research, 2(5).

Yule, G. (1996). 1996_Pragmatics by George Yule.pdf (p. 2).

Zacharias, N. T. (2011). Qualitative research methods for second language education: A coursebook. Cambridge Scholars Publishing. 